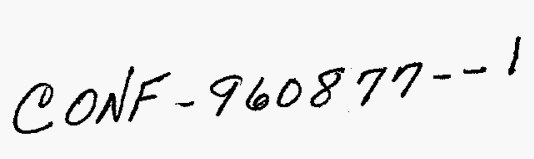

\title{
PARTITIONING BEHAVIOR OF ALLOYING ELEMENTS IN PWA 1484
}

\author{
M. K. Miller, L. S. Lin*, A. D. Cetel*, H. Harada ${ }^{*}$ and H. Murakami ${ }^{\circ}$ \\ Metals and Ceramics Division, Oak Ridge National Laboratory, Oak Ridge, TN 37831-6376; *Pratt \\ and Whitney, Materials Engineering, East Hartford, CT 06108; 'National Research Institute for \\ Metals, Tsukuba 305, Japan.
}

In order to achieve a desired set of properties, such as high creep strength and oxidation resistance, a variety of alloying elements are typically added to commercial nickel-based superalloys. Since single crystal superalloys do not require the inclusion of alloying elements to improve the grain boundary properties, there is significant scope in optimizing the composition and heat treatment of these alloys. The effectiveness of these alloying elements depends on their level and location in the different phases present in the microstructure. Therefore, it is desirable to be able to accurately measure and theoretically predict their distribution within the microstructure.

The partitioning behavior of the alloying elements in nickel-based superalloy PWA 1484 has been determined with the atom probe field ion microscope. These results have been compared with predictions generated from the "Alloy Design Program". This computer program is based on regression analysis." Of particular interest were the characterization of the partitioning behavior of hafnium between the $\gamma^{\prime} \mathrm{L}_{12}$-ordered precipitates and the $\gamma$ disordered face centered cubic matrix and the clustering behavior of the rhenium atoms in the $\gamma$ matrix.

The nominal composition of the single crystal PWA 1484 material used in this investigation was Ni10.5 at. $\% \mathrm{Co}, 6 \% \mathrm{Cr}, 1.3 \% \mathrm{Mo}, 2.0 \% \mathrm{~W}, 12.9 \% \mathrm{Al}, 3.0 \% \mathrm{Ta}, 0.04 \%$ Hf and $1.0 \% \mathrm{Re}$. All compositions quoted are given in atomic percent. The superalloy was examined after a standard heat treatment of $4 \mathrm{~h}$ at $1304^{\circ} \mathrm{C}, 4 \mathrm{~h}$ at $1079^{\circ} \mathrm{C}$ and $24 \mathrm{~h}$ at $704^{\circ} \mathrm{C}$. Specimen temperatures of between 50 and $60 \mathrm{~K}$ and a pulse fraction of $20 \%$ were used for the compositional determinations in the ORNL energy-compensated atom probe field ion microscope. ${ }^{2}$

The average compositions of the $\gamma^{\prime}$ precipitates and the $\gamma$ matrix were experimentally determined in the atom probe and are shown in Table 1. A series of estimates of the compositions of the $\gamma$ and $\gamma^{\prime}$ phases was also determined with the use of the model specifically for the nominal composition of this PWA 1484 alloy. The resuits for each of the 3 stages of the heat treatment for the $\gamma$ and $\gamma^{\prime}$ phases are summarized in Table 2 . It should be noted that the volume fraction of the $\gamma^{\prime}$ phase increases with decreasing temperature. In all cases, the expected partitioning of the alloying elements between the $\gamma$ and $\gamma^{\prime}$ phases was found. In particular, the experimental atom probe and the model results both indicate that $\mathrm{Co}, \mathrm{Cr}, \mathrm{Mo}, \mathrm{W}$ and $\mathrm{Re}$ partition to the $\gamma$ phase and $\mathrm{Ni}, \mathrm{Al}, \mathrm{Ta}$ and Hf partition to the $\gamma^{\prime}$ phase. The partitioning factors (defined as the ratios of the concentrations of the elements in the $\gamma$ and $\gamma^{\prime}$ phases) were determined from the atom probe results and the model and are summarized in Table 3. The atom probe results for $\mathrm{Co}, \mathrm{Mo}, \mathrm{W}, \mathrm{Al}, \mathrm{Hf}$ and $\mathrm{Re}$ are in reasonable agreement with the model. The results for chromium appear to be slightly over predicted and those of tantalum are slightly under predicted by the model. However, it is also possible that the equilibrium compositions had not been fully attained after $24 \mathrm{~h}$ at $704^{\circ} \mathrm{C}$ in the real material. As in previous atom probe studies of this and other nickel-based superalloys, no solute enrichments were observed at the $\gamma-\gamma^{\prime}$ interfaces in the atom probe compositional data, Fig. 1, and no evidence of local enrichments were evident in the field ion images, Fig. 2.

The distribution of rhenium in the $\gamma$ matrix was investigated by examination of the atom-by-atom data chains and by applying two statistical tests, namely the mean separation method and the Johnson and Klotz ordering parameter to the atom probe data. ${ }^{2}$ In contrast to previous atom probe results, ${ }^{3}$ neither method was able to detect the presence of rhenium clusters in the $\gamma$ matrix and there was no evidence of clustering in the field ion images. ${ }^{4}$ 


\section{DISCLAIMER}

This report was prepared as an account of work sponsored by an agency of the United States Government. Neither the United States Government nor any agency thereof, nor any of their employees, makes any warranty, express or implied, or assumes any legal liability or responsibility for the accuracy, completeness, or usefulness of any information, apparatus, product, or process disclosed, or represents that its use would not infringe privately owned rights. Reference herein to any specific commercial product, process, or service by trade name, trademark, manufacturer, or otherwise does not necessarily constitute or imply its endorsement, recommendation, or favoring by the United States Government or any agency thereof. The views and opinions of authors expressed herein do not necessarily state or reflect those of the United States Government or any agency thereof. 


\section{DISCLAIMER}

Portions of this document may be illegible in electronic image products. Images are produced from the best available original document. 
1. H. Harada, K. Ohno, T. Yamagata, T. Yokokawa and M. Yamazaki, Superalloys 1988, eds. S. Reichman, et al., The Metallurgical Society, Warrendale, (1988) 733.

2. M.K. Miller and G.D.W. Smith, Atom Probe Microanalysis: Principles and Applications to Materials Problems, Materials Research Society, Pittsburgh, PA (1989).

3. D. Blavette, P. Caron and T. Khan, Scripta Metall., 20 (1986) 1395.

4. Research partially supported by the Division of Materials Sciences, U.S. Department of Energy under contract DE-AC05-96OR22464 with Lockheed Martin Energy Research Corp. and through the SHaRE Program under contract DE-AC05-760R00033 with Oak Ridge Associated Universities.

TABLE 1. Phase compositions experimentally measured in the atom probe.

\begin{tabular}{|c|c|c|c|c|c|c|c|c|}
\hline$\gamma$ phase & $\mathrm{Co}$ & $\mathrm{Cr}$ & $\mathrm{Mo}$ & $\mathrm{W}$ & $\mathrm{Al}$ & $\mathrm{Ta}$ & $\mathrm{Hf}$ & $\mathrm{Re}$ \\
\hline Average & 22.8 & 16.9 & 2.8 & 3.2 & 3.2 & 0.28 & 0 & 3.7 \\
\hline$\gamma^{\prime}$ phase & $\mathrm{Co}$ & $\mathrm{Cr}$ & $\mathrm{Mo}$ & $\mathrm{W}$ & $\mathrm{Al}$ & $\mathrm{Ta}$ & $\mathrm{Hf}$ & $\mathrm{Re}$ \\
\hline Average & 6.1 & 2.1 & 0.9 & 2.6 & 23.5 & 6.2 & 0.08 & 0.27 \\
\hline
\end{tabular}

TABLE 2. Predictions of the phase compositions by the linear regression model.

\begin{tabular}{|c|c|c|c|c|c|c|c|c|}
\hline$\gamma$ phase & $\mathrm{Co}$ & $\mathrm{Cr}$ & $\mathrm{Mo}$ & $\mathrm{W}$ & $\mathrm{Al}$ & $\mathrm{Ta}$ & $\mathrm{Hf}$ & $\mathrm{Re}$ \\
\hline $1304^{\circ} \mathrm{C}$ & 10.6 & 5.98 & 1.30 & 2.03 & 12.9 & 2.99 & 0.03 & 1.00 \\
$1079^{\circ} \mathrm{C}$ & 13.6 & 10.0 & 2.14 & 2.44 & 8.20 & 1.32 & 0.01 & 1.93 \\
$704^{\circ} \mathrm{C}$ & 25.5 & 19.7 & 2.94 & 2.54 & 1.74 & 0.54 & 0 & 3.13 \\
\hline$\gamma^{\prime}$ phase & $\mathrm{Co}$ & $\mathrm{Cr}$ & $\mathrm{Mo}$ & $\mathrm{W}$ & $\mathrm{Al}$ & $\mathrm{Ta}$ & $\mathrm{Hf}$ & $\mathrm{Re}$ \\
\hline $1304^{\circ} \mathrm{C}$ & 8.63 & 2.20 & 0.33 & 1.34 & 15.7 & 7.75 & 0.13 & 0.09 \\
$1079^{\circ} \mathrm{C}$ & 7.86 & 2.38 & 0.55 & 1.67 & 17.1 & 4.47 & 0.06 & 0.18 \\
$704^{\circ} \mathrm{C}$ & 5.59 & 1.42 & 0.75 & 1.86 & 16.6 & 3.81 & 0.05 & 0.29 \\
\hline
\end{tabular}

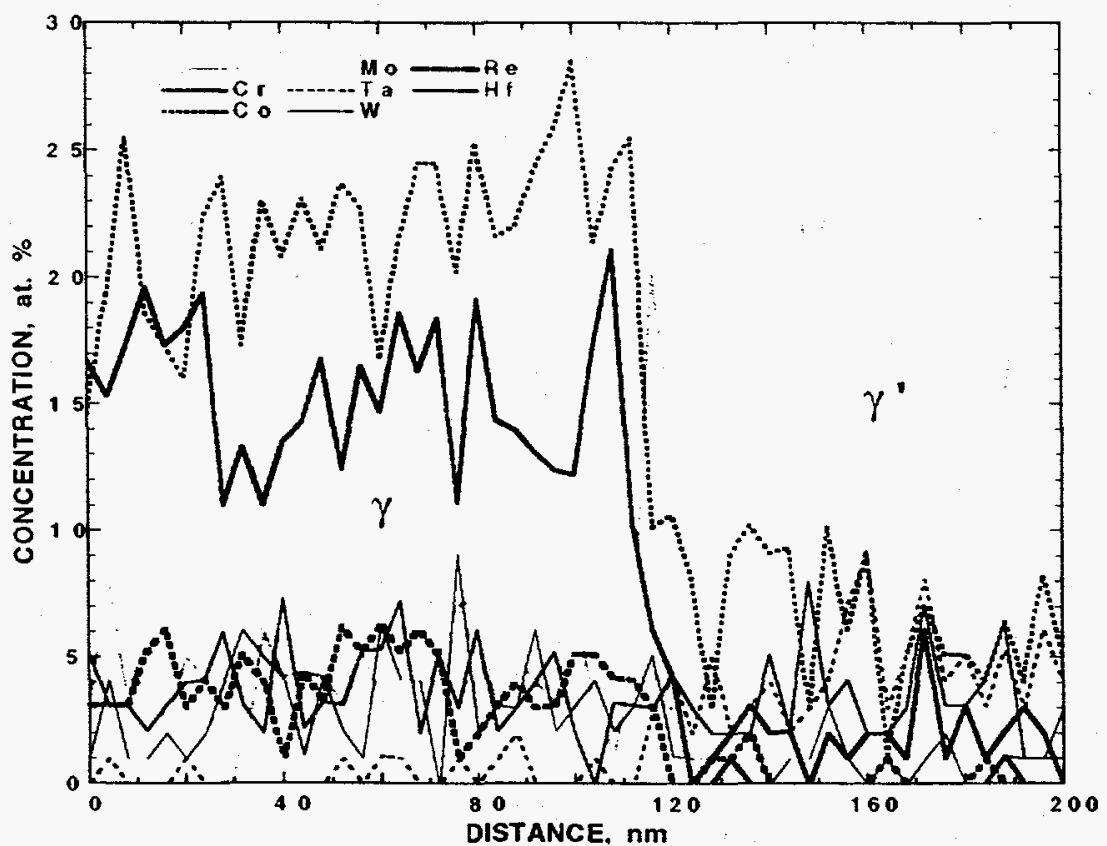

FIG. 1. Composition profile through a $\gamma-\gamma^{\prime}$ interface.
TABLE 3. Comparison of the partitioning factors of $\gamma: \gamma^{\prime}$ compositions determind from the atom probe experiments and the $704^{\circ} \mathrm{C}$ results from the linear regression model.

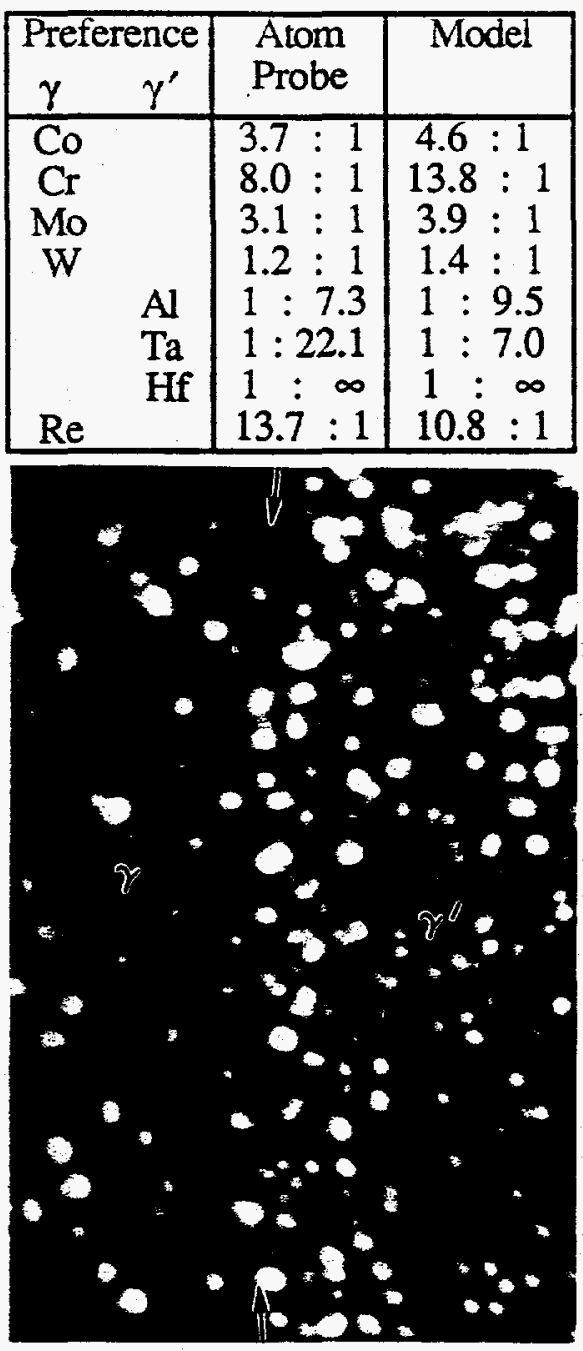

FIG. 2. Field ion micrograph of PWA 1484 after the three stage heat treatment. 